\title{
CCT327 enhances TRAIL-induced apoptosis through the induction of death receptors and downregulation of cell survival proteins in TRAIL-resistant human leukemia cells
}

\author{
YAN-JIN LIU ${ }^{1}$, YING-CHAO LIN ${ }^{2,3}$, JANG-CHANG LEE ${ }^{4}$, SHENG-CHU KUO ${ }^{1}$, CHI-TANG HO ${ }^{5}$, \\ LI-JIAU HUANG ${ }^{1}$, DAIH-HUANG KUO ${ }^{6}$ and TZONG-DER WAY ${ }^{7-9}$
}

${ }^{1}$ Graduate Institute of Pharmaceutical Chemistry, College of Pharmacy, China Medical University, Taichung;

${ }^{2}$ Division of Neurosurgery, Buddhist Tzu Chi General Hospital, Taichung Branch, Taichung;

${ }^{3}$ School of Medicine, Tzu Chi University, Hualien; ${ }^{4}$ Department of Pharmacy, China Medical University,

Taichung, Taiwan, R.O.C.; ${ }^{5}$ Department of Food Science, Rutgers University, New Brunswick, NJ, USA;

${ }^{6}$ Graduate Institute of Pharmaceutical Technology, College of Pharmacy and Health Care, Tajen University, Pingtung;

${ }^{7}$ Department of Biological Science and Technology, College of Life Sciences, China Medical University, Taichung;

${ }^{8}$ Institute of Biochemistry, College of Life Science, National Chung Hsing University, Taichung;

${ }^{9}$ Department of Health and Nutrition Biotechnology, College of Health Science, Asia University,

Taichung, Taiwan, R.O.C.

Received March 7, 2014; Accepted May 20, 2014

DOI: $10.3892 /$ or.2014.3317

\begin{abstract}
Tumor necrosis factor-related apoptosis-inducing ligand (TRAIL) has potential application in cancer therapy and it has the ability to selectively kill cancer cells without affecting normal cells. However, the development of resistance to TRAIL in cancer cells cannot be avoided. This study investigated the effects of 2-(5-methylselenophen-2-yl)-6,7-methylenedioxyquinolin-4-one (CCT327), an analogue of quinolin-4-one, on the sensitization of cancer cells to TRAIL and on TRAIL-induced apoptosis in TRAIL-resistance human leukemia cells (HL60-TR). We found that CCT327 enhanced TRAIL-induced apoptosis through upregulation of death receptors DR4 and DR5. In addition to upregulating DRs (death receptors), CCT327 suppressed the expression of decoy receptor DcR1. CCT327 significantly downregulated the expression of FLICE inhibitory protein (cFLIP) and other antiapoptotic proteins. We also demonstrated that CCT327 could activate p38 and JNK. Moreover, CCT327induced induction of DR5 and DR4 was mediated by reactive oxygen species (ROS), and N-acetylcysteine (NAC) blocked
\end{abstract}

Correspondence to: Professor Daih-Huang Kuo, Graduate Institute of Pharmaceutical Technology, College of Pharmacy and Health Care, Tajen University, 20 Weixin Road, Yanpu Township, Pingtung 90741, Taiwan, R.O.C.

E-mail:kuo8765@yahoo.com.tw

Professor Tzong-Der Way, Department of Biological Science and Technology, College of Life Sciences, China Medical University, 91 Hsueh-Shih Road, Taichung 40402, Taiwan, R.O.C.

E-mail: tdway@mail.cmu.edu.tw the induction of DRs by CCT327. Taken together, these results showed that CCT327 combined with TRAIL treatment may provide an effective therapeutic strategy for cancer.

\section{Introduction}

The tumor necrosis factor (TNF)-related apoptosis-inducing ligand (TRAIL) is a member of the TNF superfamily, and is an attractive anticancer agent. The ability of TRAIL includes the selective killing of a variety of cancer cells without affecting normal cells (1-4). TRAIL is one of the most promising experimental cancer therapeutic drugs and is presently being tested

Abbreviations: CCT327, 2-(5-methylselenophen-2-yl)-6,7-methylenedioxyquinolin-4-one; 2PQs, 6,7-substituted 2-phenylquinolin-4ones; TRAIL, tumor necrosis factor (TNF)-related apoptosisinducing ligand; MTT, 3-(4,5-dimethylthiazol-2-yl)-2,5-diphenyltetrazolium bromide; DMSO, dimethyl sulfoxide; PI, propidium iodide; NAC, N-acetylcysteine; DR, death receptor; DcR, decoy receptor; OPG, osteoprotegerin; FADD, Fas-associated protein with death domain; DISC, death-inducing signaling complex; PARP, poly (ADP-ribose) polymerase; ROS, reactive oxygen species; FLICE, FADD-like interleukin-1 $\beta$ converting enzyme; c-FLIP, FLICE inhibitory protein; MAPKs, mitogen-activated protein kinases; JNK, c-Jun $\mathrm{N}$-terminal kinase; ERK, extracellular signal-regulated kinase; FBS, fetal bovine serum; SDS-PAGE, sodium dodecyl sulfate-polyacrylamide; ECL, enhanced chemiluminescence; PBS, phosphate-buffered saline; RPMI-1640, Roswell Park Memorial Institute-1640

Key words: TRAIL, CCT327, human leukemia cells, ROS, death receptor 
in clinical trials (5-8). To date, five different TRAIL receptors have been identified: death receptor DR4 (TRAIL-R1) and DR5 (TRAIL-R2), decoy receptor DcR1 and DcR2 and osteoprotegerin (OPG). DR4 and DR5 are able to transduce an apoptotic signal, whereas the other three (DcR1, DcR2 and OPG) are decoy receptors to impede TRAIL-induced apoptosis, and play a dominant-negative role by competing with DR4 and DR5 for interaction with TRAIL (9-12).

The binding of TRAIL to two closely related receptors, DR4 and DR5, leads to recruitment of the adaptor protein, Fas-associated protein with death domain (FADD) and initiator caspase-8 to form the death-inducing signaling complex (DISC). This process leads to the cleavage and activation of caspase-8, which in turn activates the downstream caspase cascade, such as caspase- 9 and -3 in the presence or absence of mitochondrial amplification machinery (13-18). However, human cancer cell lines and primary tumor cells are found to develop resistance to TRAIL through intrinsic or acquired resistance mechanisms. This resistance is mediated through deregulation of apoptotic-related signaling molecules, such as downregulation of DR4, DR5, caspase-8, or Bax and enhanced expression of antiapoptotic molecules such as survivin, or overexpression of the Bcl-2 family proteins (19-21). FLICE causes the activation of caspase-8, and FLICE-like inhibitors such as cFLIP have been reported to bind to caspase- 8 and impede the activation of downstream incidents leading to apoptosis, including TRAIL-mediated apoptosis (22-25). Consequently, the relationship between tumors and TRAIL has caused a large interest in understanding the effector mechanisms and the search for novel compounds which can resensitize tumor cells to TRAIL-induced apoptosis.

Reactive oxygen species (ROS), such as superoxide, $\mathrm{H}_{2} \mathrm{O}_{2}$ and hydroxyl radicals, trigger a variety of cellular responses leading to cell growth, differentiation, or cell death (26-31). Mitogen-activated protein kinases (MAPKs), such as stress activated protein kinase/c-Jun N-terminal kinase (JNK), extracellular signal-regulated kinase (ERK) and p38 are principal mediators of the ROS-induced signaling pathway (31-35). In addition, when MAPKs are activated, this triggers diverse signaling cascades resulting in cell proliferation, differentiation or cell death in various tumor cells $(30,34-39)$.

Several 6,7-substituted 2-phenylquinolin-4-ones (2PQs) have been synthesized and identified as novel antimitotic agents (40). Recently, novel 2-selenophenyl quinolin-4-ones and their isosteric compounds were designed, synthesized and evaluated for their in vitro anticancer activity. The most promising target compound, 2-(5-methylselenophen-2-yl)-6,7-methylenedioxyquinolin-4-one (CCT327) excibited highly selective and potent growth inhibition against MDA-MB-435 melanoma. CCT327 regulates the expression of mitotic phase- and apoptosis-associated proteins. СCT327 was found to decrease the expression of cyclin B1 and CDK1 proteins in a concentration-dependent manner in HL-60 cells. In addition, CCT327 was found to activate caspase-3 and poly(ADP-ribose) polymerase (PARP) cleavage (41). However, whether CCT327 can sensitize tumor cells to TRAIL-induced apoptosis is not known. In this study, we attempted to ascertain the effect of CCT327 on TRAIL-induced apoptosis in TRAIL-resistance human leukemia cells. Our investigation showed that CCT327 sensitized TRAIL-induced apoptosis through the upregulation of DR4 and DR5 expression and the downregulation of cFLIP, and other antiapoptotic proteins. Furthermore, JNK and p38 regulated the expression of DR4 and DR5 via a ROS-mediated mechanism.

\section{Materials and methods}

Chemicals and reagents. CCT327 was synthesized in our laboratory (Fig. 1A). Recombinant soluble human TRAIL was purchased from PeproTech (Rocky Hill, NJ, USA). Primary antibodies against caspase-3, caspase-8 and caspase-9, PARP, Bcl-2, survivin, JNK, phospho-JNK, ERK1/2, phosphoERK1/2, p38 and phospho-p38 were purchased from Cell Signaling Technology (Danvers, MA, USA). DcR1 and DcR2 antibodies were purchased from ProSci Inc. (Poway, CA, USA). Antibodies against Bax, FLIP $_{S} /$ FLIP $_{\mathrm{L}}$ and Bid were purchased from Santa Cruz Biotechnology (Santa Cruz, CA, USA). Primary DR4 and DR5 were purchased from Abcam Inc. (Cambridge, MA, USA) and Novus Biologicals (Littleton, CO, USA), respectively. Secondary antibodies, HRP-conjugated goat anti-mouse $\operatorname{IgG}$ and goat anti-rabbit IgG, were obtained from Millipore (Billerica, MA, USA). Cell culture materials were obtained from Invitrogen Corp. (Carlsbad, CA, USA). 3-(4,5-Dimethylthiazol-2-yl)-2,5-diph enyltetrazolium bromide (MTT), propidium iodide (PI) and antibodies for $\beta$-actin were purchased form Sigma (St. Louis, MO, USA). PD98059, SB203580 and SP600125 were obtained from Calbiochem (San Diego, CA, USA).

Cell lines and cell cultures. The human leukemia cancer cell line used in this study was HL60 (CCL 240) from the parental cell line obtained from the American Type Culture Collection (Manassas, VA, USA). HL60 cells derived from a human acute promyelocytic leukemia are usually sensitive to chemotherapeutic drugs and TRAIL. TRAIL-resistant HL60 cells (HL60-TR) were selected by exposure of HL60 cells to escalating doses of TRAIL $(10 \mathrm{ng} / \mathrm{ml}, 20 \mathrm{ng} / \mathrm{ml}, 50 \mathrm{ng} / \mathrm{ml}$, $100 \mathrm{ng} / \mathrm{ml}, 500 \mathrm{ng} / \mathrm{ml}, 1 \mu \mathrm{g} / \mathrm{ml}, 5 \mu \mathrm{g} / \mathrm{ml}$ and $10 \mu \mathrm{g} / \mathrm{ml}$ ) for 2 to 3 days. After each exposure, surviving cells were recovered and cultured in fresh medium for 3 days and then treated with the subsequent dose (42). HL60-TR cells were routinely maintained in RPMI-1640 (Invitrogen). Medium was supplemented with $2 \mathrm{mM} \mathrm{L}$-glutamine, $100 \mu \mathrm{g}$ streptomycin, $100 \mathrm{U}$ penicillin and $10 \%$ fetal bovine serum (FBS) (Invitrogen). Cells were grown in a humidified incubator at $37^{\circ} \mathrm{C}$ under $5 \%$ $\mathrm{CO}_{2}$ in air.

Cytotoxicity assay. In brief, cells were seeded on a 24-well plate $\left(1 \times 10^{4}\right.$ cells/well $)$ overnight and then treated with different concentrations of CCT327 and TRAIL as indicated in the figure legends and then incubated for $48 \mathrm{~h}$. Following treatments, $80 \mu \mathrm{l}$ of MTT (stock concentration $2 \mathrm{mg} / \mathrm{ml}$ ) was added to each well and incubated for $2 \mathrm{~h}$ under $5 \% \mathrm{CO}_{2}$ at $37^{\circ} \mathrm{C}$. The cell viability was measured by MTT, which is converted by succinate dehydrogenase in the mitochondria of viable cells to form a purple formazan dye by metabolically viable cells. The formazan dye was dissolved in dimethyl sulfoxide (DMSO). To measure the absorbance, an enzymelinked immunosorbent assay (ELISA) reader was used at OD $570 \mathrm{~nm}$. 
A<smiles>Cc1ccc(-c2cc(=O)c3cc4c(cc3[nH]2)OCO4)[se]1</smiles>

C

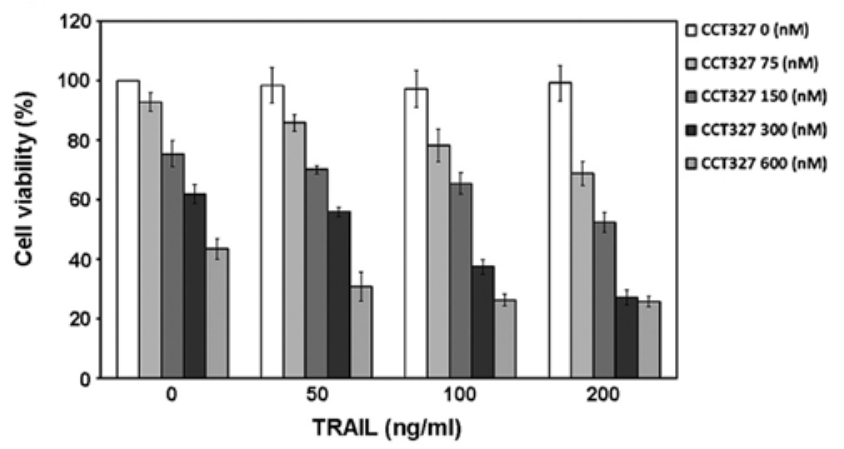

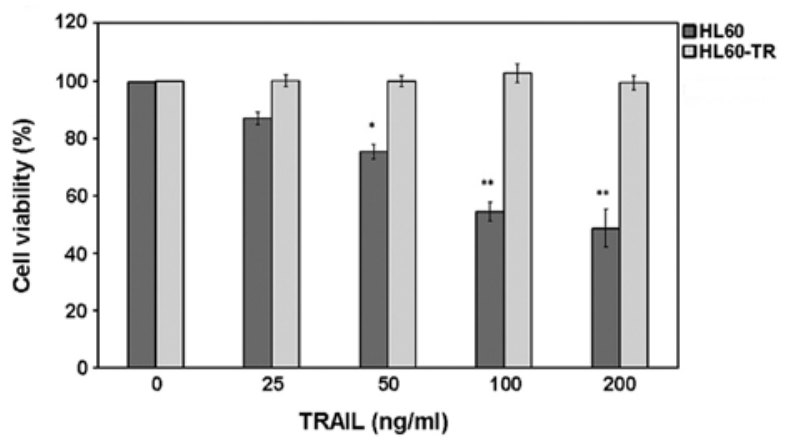

D

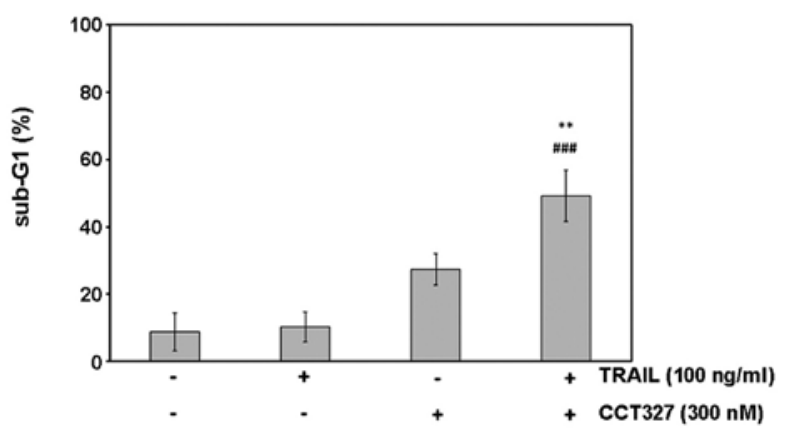

$\mathbf{E}$

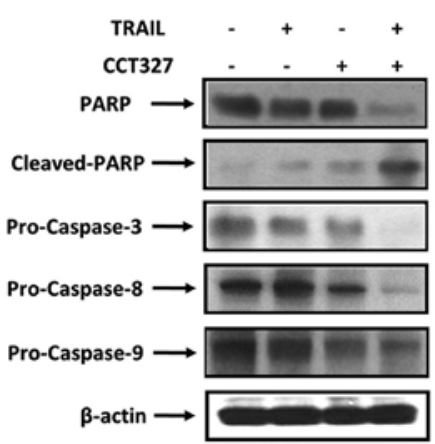

Figure 1. CCT327-potentiated as TRAIL-induced apoptosis of HL60-TR cells. (A) Chemical structure of 2-(5-methylselenophen-2-yl)-6,7-methylenedioxyquinolin-4-one (CCT327). (B) Dose-response curves for HL60 and HL60-TR cells treated with TRAIL. Cells $\left(1 \times 10^{4}\right)$ were treated with TRAIL $(0,25,50,100$, $200 \mathrm{ng} / \mathrm{ml}$ ) for $48 \mathrm{~h}$, and cell viability was quantitated by MTT assay. In comparison with HL60 cells, HL60-TR cells were resistant to induction of apoptosis by TRAIL. Data are expressed as mean \pm SEM. ${ }^{*} \mathrm{P}<0.05$ and ${ }^{* *} \mathrm{P}<0.01$, significant difference as compared to HL60-TR. (C) HL60-TR cells (1x10 $/$ well) were plated in 24-well plates for $48 \mathrm{~h}$ and treated with various concentrations of CCT327 $(0,75,150,300$ or $600 \mathrm{nM})$ and TRAIL (0, 50, $100 \mathrm{or} 200 \mathrm{ng} / \mathrm{ml})$. Cell viability was determined by MTT assay, as described in Materials and methods. Data are expressed as mean \pm SEM. (D) HL60-TR cells $\left(5 \times 10^{5}\right)$ were treated with TRAIL (100 ng/ml) and with CCT327 (300 nM) or without for $48 \mathrm{~h}$. Cells were stained with PI, and the sub-G1 fraction was analyzed using flow cytometry. Data are expressed as mean \pm SEM. ${ }^{* *} \mathrm{P}<0.01$, significant difference as compared to CCT327; ${ }^{\# \# \#} \mathrm{P}<0.001$, significant difference as compared to TRAIL. (E) HL60-TR cells were treated with CCT327 $(300 \mathrm{nM})$ and with TRAIL (100 ng/ml) or without for $48 \mathrm{~h}$. Whole-cell extracts were prepared and analyzed by western blotting using antibodies against pro-caspase- $3,-8,-9$ and PARP. The same blots were stripped and reprobed with $\beta$-actin antibody to verify equal protein loading. TRAIL, tumor necrosis factor (TNF)-related apoptosis-inducing ligand; PARP, poly(ADP-ribose) polymerase; PI, propidium iodide.

Flow cytometric analysis. To determine the effect of CCT327 plus TRAIL on the cell cycle distribution, treated and untreated cells were stained with PI as mentioned earlier. Briefly, $5 \times 10^{5}$ cells were treated with CCT327 plus TRAIL for $48 \mathrm{~h}$ at $37^{\circ} \mathrm{C}$ and subjected to PI staining. Cells were collected by trypsinization, fixed with $70 \%(\mathrm{v} / \mathrm{v})$ ethanol at $4^{\circ} \mathrm{C}$ for $30 \mathrm{~min}$ and washed with phosphate-buffered saline (PBS). After centrifugation, cells were resuspended in $500 \mu \mathrm{l}$ of PI solution comprising Triton X-100 (0.1\%, v/v), RNase $(100 \mathrm{mg} / \mathrm{ml})$ and PI $(80 \mathrm{mg} / \mathrm{ml})$ and then analyzed with FACScan and the Cell Quest software (Becton-Dickinson, Mountain View, CA, USA) (43).
Western blotting. HL60-TR cells on 100-mm culture dishes $\left(1 \times 10^{6}\right.$ cells/dish) were treated with various agents as indicated in the figure legends and were then incubated for $48 \mathrm{~h}$. Cells were harvested and the protein fraction was extracted by adding $50 \mu \mathrm{l}$ of Gold lysis buffer $(50 \mathrm{mM}$ Tris-HCl, $\mathrm{pH} 7.4$; $1 \mathrm{mM}$ phenylmethylsulfonyl fluoride; $1 \mathrm{mM} \mathrm{NaF} ; 1 \%$ NP-40; $150 \mathrm{mM} \mathrm{NaCl} ; 1 \mathrm{mM}$ EGTA and $10 \mathrm{mg} / \mathrm{ml}$ leupeptin) to the cell pellets. Lysate protein was measured by the Lowry protein assay (Bio-Rad Laboratories, Berkeley, CA, USA). Proteins between 50 and $100 \mu \mathrm{g}$ were used for the sodium dodecyl sulfate-polyacrylamide gel electrophoresis (SDS-PAGE) and transferred to a polyvinylidene fluoride (PVDF) membrane 

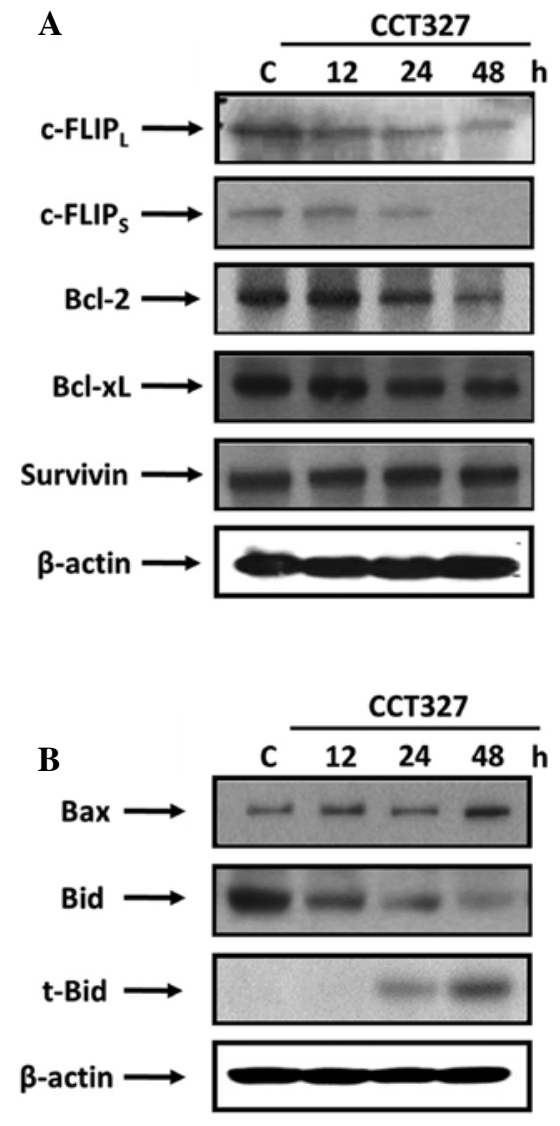

Figure 2. Effects of CCT327 on the expression of antiapoptotic and proapoptotic proteins. HL60-TR cells were treated with $300 \mathrm{nM} \mathrm{CCT327} \mathrm{for} \mathrm{the}$ indicated times. Whole-cell extracts were prepared and analyzed by western blotting using antibodies against antiapoptotic (A) and proapoptotic (B) proteins. The same blots were stripped and reprobed with $\beta$-actin antibody to verify equal protein loading. C, control; CCT327, 2-(5-methylselenophen-2-yl)-6,7-methylenedioxyquinolin-4-one.

(Biotrace, UK). The blotted membrane was blocked with 5\% skim milk for $1 \mathrm{~h}$ at room temperature and probed with the primary antibody overnight at $4^{\circ} \mathrm{C}$. Finally, HRP-conjugated appropriated secondary antibodies were used for $1 \mathrm{~h}$.

Statistical analysis. One-way analysis of variance (ANOVA) was used for the comparison of more than 2 mean values. The results represent at least two to three independent experiments and are shown as averages \pm SEM. Results with a P-value $<0.05$ were considered statistically significant $(\mathrm{P}<0.05, \mathrm{P}<0.01$, $\mathrm{P}<0.001$ as indicated in the figure legends).

\section{Results}

CCT327 sensitizes HL60-TR cells to TRAIL-mediated apoptosis. We first examined the sensitivity of HL60 and HL60-TR cells to TRAIL. HL60 and HL60-TR cells were treated with increasing doses of recombinant TRAIL and were then assessed for cell viability using the MTT method. The dose-response of HL60 and HL60-TR cells to TRAIL is shown in Fig. 1B. The HL60 cells were found to be highly sensitive to TRAIL whereas the HL60-TR cells were completely resistant (Fig. 1B). Therefore, the HL60-TR cells were used for a detailed investigation of the resistance mechanisms.
We next aimed to ascertain whether CCT327 enhances TRAIL-induced apoptosis in HL60-TR cells. HL60-TR cells were treated with CCT327 (0-600 nM) and then exposed to TRAIL (0-200 ng/ml) for $48 \mathrm{~h}$. Treatment with TRAIL had no effect on cell viability. However, combination treatment with CCT327 and TRAIL significantly enhanced TRAIL-induced cytotoxicity (Fig. 1C). To further confirm the effect of CCT327 on TRAIL-induced apoptosis, we also investigated the distribution of cells by PI staining. The percentage of apoptotic cells in the sub-G1 peak as evidenced by the increase in subdiploid fraction of treated cells was measured by flow cytometry. We found that TRAIL-induced apoptosis was increased from 9.7 to $50.8 \%$ in the HL60-TR cells (Fig. 1D). Thus, our results indicated that CCT327 converted the TRAIL-resistant HL60-TR cells to TRAIL-sensitive cells.

Activation of caspases is an important hallmark of apoptosis induced by most agents. We next investigated whether the effect of CCT327 on TRAIL-induced cell death was through activation of caspase- $8,-9$ and -3 and PARP cleavage. Treatment with $300 \mathrm{nM}$ CCT327 alone had little effect on the cleavage of procaspase-3, -8, -9 and PARP (Fig. 1E). Moreover, TRAIL alone did not induce processing of any caspases. Co-treatment with CCT327 and TRAIL effectively induced activation of all three caspases, thus leading to enhanced PARP cleavage. These results suggest that CCT327 can enhance TRAIL-induced apoptosis. The activation of caspases by CCT327 was essential for the stimulation of TRAIL-mediated apoptosis.

CCT327 inhibits the expression of antiapoptotic proteins. Several antiapoptotic proteins are known to suppress TRAIL-induced apoptosis. The mechanism by which CCT327 enhances TRAIL-induced apoptosis was next investigated. HL60-TR cells were exposed to $300 \mathrm{nM}$ CCT327 for different times and were then examined for the expression of $\mathrm{cFLIP}_{\mathrm{L}}$ and cFLIP $_{S}$ (long and short), Bcl-2, Bcl-xL and survivin. CCT327 suppressed expression of the antiapoptotic proteins such as Bcl-2 and both the short and long forms of cFLIP (Fig. 2A). It had no effect on the expression of survivin. Expression of Bcl-xL was not distinct. Our results suggest that downregulation of antiapoptotic proteins is another mechanism by which CCT327 sensitizes TRAIL-induced apoptosis.

CCT327 regulates the expression of proapoptotic proteins. Whether CCT327 affects the expression of proapoptotic proteins was next examined. CCT327 caused the cleavage of bid protein and enhanced the expression of proapoptotic protein bax (Fig. 2B). Induction of bid and bax by CCT327 suggests that these proteins may disrupt mitochondrial homeostasis, which further contributes to the enhancement of the apoptotic effects of TRAIL.

CCT327 induces the expression of DR4 and DR5 in HL60-TR cells. To understand how CCT327 enhances TRAIL-induced apoptosis, we investigated its effect on DR4 and DR5 in HL60-TR cells. Treatment of HL60-TR cells with $300 \mathrm{nM}$ CCT327 induced expression of DR4 and DR5 in a time-dependent manner (Fig. 3A, left). Treatment with different concentrations of CCT327 to HL60-TR cells for $48 \mathrm{~h}$ induced both DR4 and DR5 in a dose-dependent manner (Fig. 3A, right). Fig. 3B shows that treatment with TRAIL alone had 
A

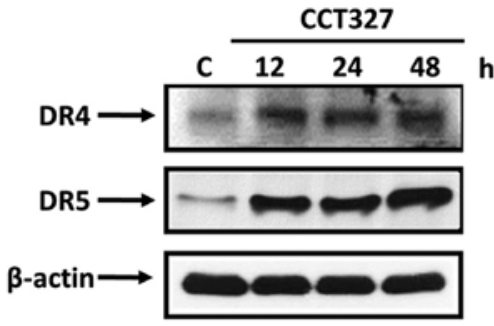

B

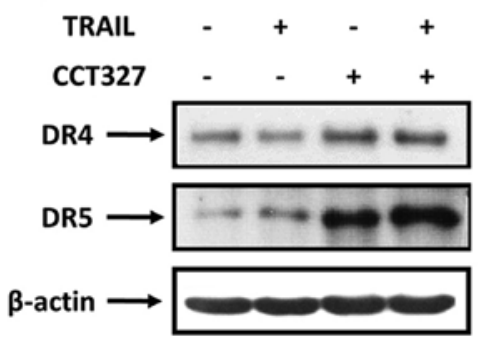

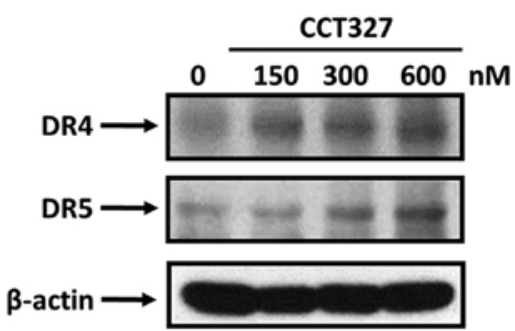

C

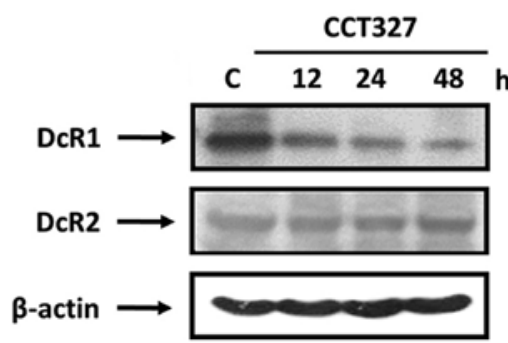

Figure 3. CCT327 induces DR5 and DR4 expression and suppresses decoy receptors. (A) HL60-TR cells (1x10 ${ }^{6}$ cells) were treated with $300 \mathrm{~nm}$ CCT37 for 12, 24 or $48 \mathrm{~h}$ (left panel) or with $0,150,300$ or $600 \mathrm{~nm}$ for $48 \mathrm{~h}$ (right panel). (B) HL60-TR cells were treated with TRAIL (100 ng/ml) and with CCT327 $(300 \mathrm{nM})$ or without for $48 \mathrm{~h}$. Whole-cell extracts were prepared and analyzed for DR4 and DR5 expression by western blotting. (C) HL60-TR cells were treated with CCT327 (300 nM) for 12, 24 or $48 \mathrm{~h}$. Whole-cell extracts were prepared and analyzed for DcR1 and DcR2 expression by western blotting. Western blotting data presented are representative of those obtained in at least 3 separate experiments. $\beta$-actin was used as a loading control. CCT327, 2-(5-methylselenophen-2-yl)-6,7-methylenedioxyquinolin-4-one; TRAIL, tumor necrosis factor (TNF)-related apoptosis-inducing ligand; DR, death receptor; DcR, decoy receptor.

A

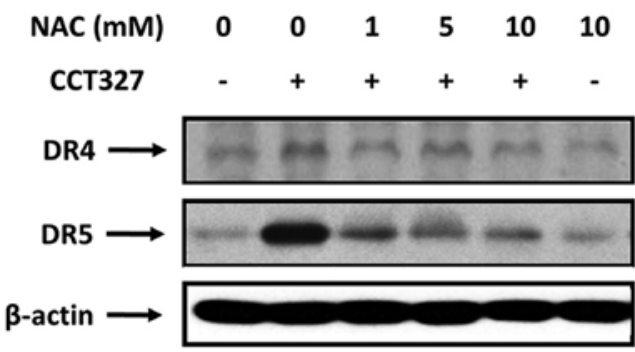

B

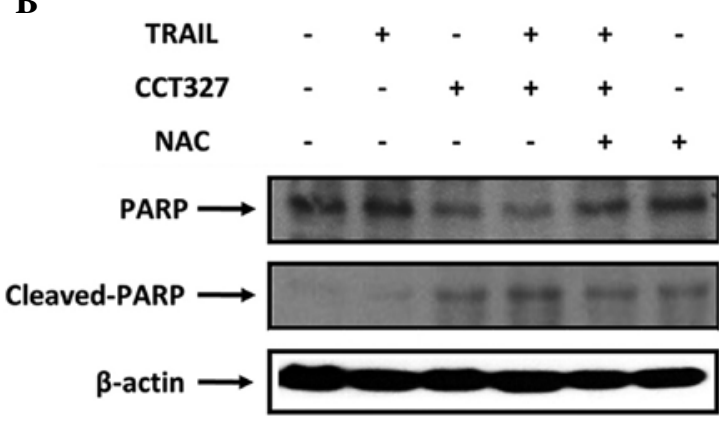

Figure 4. Upregulation of DR4 and DR5 by CCT327 is mediated by ROS. (A) HL60-TR cells $\left(1 \times 10^{6}\right.$ cells) were pretreated with various concentrations of NAC for $1 \mathrm{~h}$ and then cells were treated with $300 \mathrm{nM} \mathrm{CCT327} \mathrm{for} 48 \mathrm{~h}$. Whole-cell extracts were prepared and analyzed for DR4 and DR5 expression by western blotting. (B) NAC inhibited PARP cleavage induced by the combination of TRAIL and CCT327. HL60-TR cells ( $1 \times 10^{6}$ cells) were pretreated with $10 \mathrm{mM} \mathrm{NAC}$ for $1 \mathrm{~h}$ and then treated with $300 \mathrm{nM}$ CCT327 or $100 \mathrm{ng} / \mathrm{ml}$ TRAIL for $48 \mathrm{~h}$ as indicated. Whole-cell extracts were prepared and analyzed for PARP and cleaved-PARP expression by western blotting. Equal protein loading was evaluated by $\beta$-actin. DR, death receptor; CCT327, 2-(5-methylselenophen-2-yl)-6,7-methylenedioxyquinolin-4-one; ROS, reactive oxygen species; NAC, $\mathrm{N}$-acetylcysteine; PARP, poly(ADP-ribose) polymerase; TRAIL, tumor necrosis factor (TNF)-related apoptosis-inducing ligand. no effect on DR4 and DR5. However, combination treatment with CCT327 (300 nM) and TRAIL (100 ng/ml) significantly enhanced the expression of DR4 and DR5 in HL60-TR cells. These data show that CCT327 regulated DR4 and DR5 that both play a major role in TRAIL-induced apoptosis. This is another mechanism by which CCT327 enhanced the proapoptotic effects of TRAIL in HL60-TR cells.

CCT327 downregulates decoy receptors. Decoy receptors compete with the death receptors for ligand binding and thereby inhibit ligand-induced apoptosis (9-12). Therefore, we next examined whether CCT327 modulates the expression of DcRs. We found that CCT327 decreased the expression of DcR1, but did not influence the level of DcR2 (Fig. 3C). Thus, CCT327 may potentiate TRAIL-induced apoptosis by inhibition of DcR1.

CCT327-induced upregulation of TRAIL receptors is dependent on ROS. Several studies have reported that TRAIL-induced apoptosis is regulated by ROS (47-51). We attempted to ascertain whether CCT327-induced TRAIL receptors are also regulated by ROS. Our data showed that pretreatment of HL60-TR cells with the ROS scavenger $\mathrm{N}$-acetylcysteine (NAC) reduced the CCT327-induced upregulation of both DR5 and DR4 expression in a dose-dependent manner (Fig. 4A). This suggests that ROS is involved in the induction of TRAIL receptors by CCT327. Next, we examined whether ROS is needed for potentiation of TRAIL-induced apoptosis by CCT327. As shown in Fig. 4B, we found that pretreatment with NAC abolished the effect of CCT327 on TRAIL-induced cleavage of PARP. These results show that CCT327 potentiated TRAIL-induced apoptosis through ROS. 
A

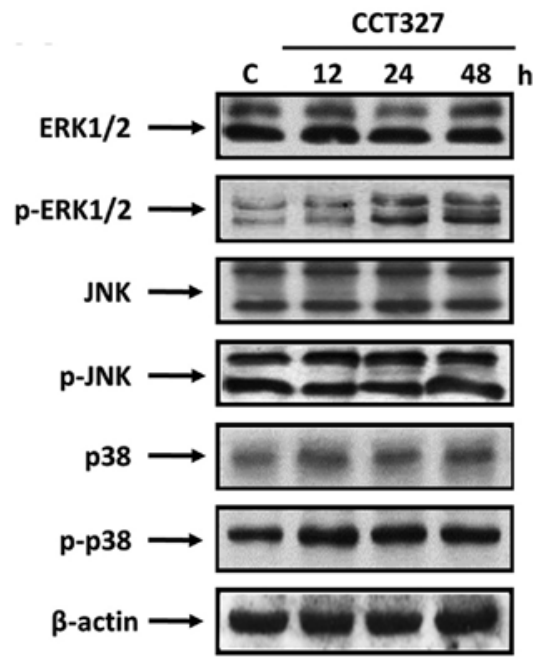

C

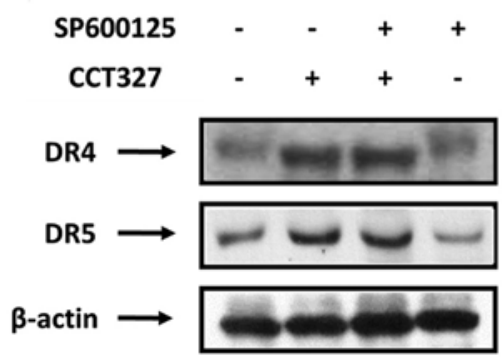

B

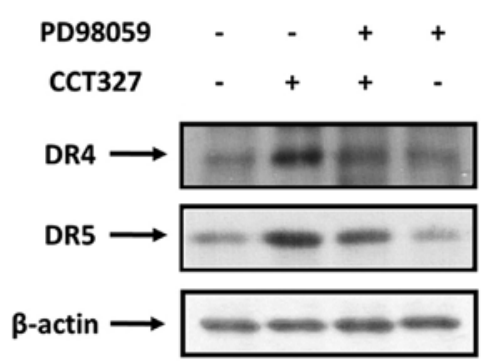

D

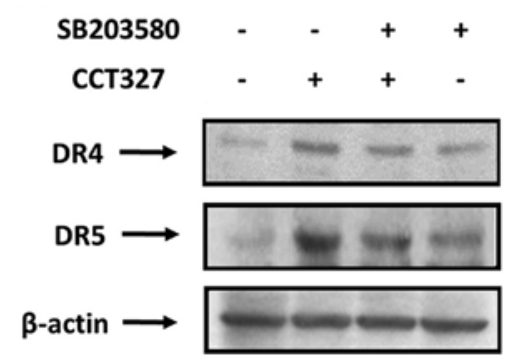

Figure 5. Upregulation of death receptors is ERK1/2- and p38-dependent. (A) HL60-TR cells (1x106 cells) were treated with $300 \mathrm{nM} \mathrm{CCT327} \mathrm{as} \mathrm{indicated,} \mathrm{and}$ whole-cell extracts were subjected to western blotting for phosphorylated ERK1/2, p38 and JNK. The same blots were stripped and reprobed with ERK1/2, p38 and JNK to ensure equal loading. HL60-TR cells were pretreated with (B) $20 \mu \mathrm{M}$ of the ERK1/2 inhibitor, PD98059; (C) $20 \mu \mathrm{M}$ of the JNK inhibitor, SP600125; and (D) $10 \mu \mathrm{M}$ of the p38 inhibitor, SB203580 for $1 \mathrm{~h}$ and were then treated with $300 \mathrm{nM} \mathrm{CCT327} \mathrm{for} 48 \mathrm{~h}$ as indicated. Whole-cell extracts were prepared and analyzed by western blotting using DR4 and DR5 antibodies. $\beta$-actin was used as a loading control. ERK, extracellular signal-regulated kinase; CCT327, 2-(5-methylselenophen-2-yl)-6,7-methylenedioxyquinolin-4-one; JNK, c-Jun N-terminal kinase; DR, death receptor.

CCT327-induced upregulation of TRAIL receptors is mediated through the activation of MAPKs. MAPKs, including ERK1/2, p38 and JNK, have been reported to mediate induction of TRAIL receptors $(47,49)$. Therefore, we ascertained whether CCT327 activates ERK1/2, p38 and JNK. Cells were pretreated with CCT327 for different times and were then examined for phosphorylated ERK, JNK and p38. We found that CCT327 activated ERK1/2 in a time-dependent manner (Fig. 5A). No activation of JNK was noted. In addition, activation of $\mathrm{p} 38$ was observed (Fig. 5A). Our result showed that induction of TRAIL receptors by CCT327 required ERK1/2 and $\mathrm{p} 38$. Next, we also determined whether these MAPKs have any effect on CCT327-induced TRAIL receptors. Cells were pretreated with $20 \mu \mathrm{M}$ of the ERK1/2 inhibitor (PD98059), $20 \mu \mathrm{M}$ of the JNK inhibitor (SP600125) and $10 \mu \mathrm{M}$ of the p38 inhibitor (SB202190), respectively (52). Both the ERK1/2 inhibitor (Fig. 5B) and the p38 inhibitor (Fig. 5D) suppressed the CCT327-induced upregulation of DR4 and DR5. No effect of the JNK inhibitor was observed on CCT327-induced DR4 and DR5 expression. Upregulation of TRAIL receptors by CCT327 was reversed by inhibitors of ERK1/2 and p38. Thus, the activation of ERK1/2 and p38 is consistent with the results obtained with the effect of their inhibitors on the CCT327-induced expression of TRAIL receptors.

\section{Discussion}

TRAIL is the only cytokine that is being explored as an anticancer agent among all the apoptosis-inducing cytokines. The unique property of triggering apoptosis in a variety of human cancer cells while sparing normal cells makes TRAIL a highly promising cancer therapeutic agent $(2,3)$. Both TRAIL and the agonistic antibodies against the receptor are presently in phase II clinical trial (53). TRAIL induces apoptosis through recognizing and binding to its cognate death receptors, DR4 and DR5 (also named as TRAIL-R1 and TRAIL-R2), on the cell surface. Upon ligand stimulation, DRs (Fas or death receptor 4/5, DR4/5) recruit FADD and the initiator caspases, caspase- 8 or caspase-10, resulting in the formation of DISC, thereby inducing death signaling and the apoptosis pathway $(9,10)$. However, TRAIL resistance is a major limitation to its clinical application as a cancer therapeutic agent. Nevertheless, a previous study demonstrated that the resistance of cancer cells to TRAIL is one of the major roadblocks to the development of this therapy (21). Thus, efforts to identify agents that activate DRs or block antiapoptotic effectors may improve therapeutic design.

In our previous report, we introduced and described a novel compound, ССТ327, which has been shown to induce 
apoptosis in human leukemia cancer cells (41). Research has shown convincing data that the upregulation of DR4 or/and DR5 could sensitize TRAIL-resistant cells to TRAIL-induced cell death (49-52). We showed that CCT327 sensitized TRAIL-induced apoptosis through modulation of death receptors. Our results also indicate that DR4 and DR5 are involved in the reversal of TRAIL-resistance by CCT327.

Research has shown that resistance to TRAIL can be due to several mechanisms, including overexpression of antiapoptotic proteins and decoy receptors (21). CCT327 decreased the expression of DcR1, but it did not influence the level of DcR2. In addition to the induction of DcR1, we also found that CCT327 downregulated expression of antiapoptotic proteins including cFLIP (long and short), Bcl-2, Bcl-xL and survivin. The effect was most pronounced on $\mathrm{cFLIP}_{\mathrm{S}}$ and

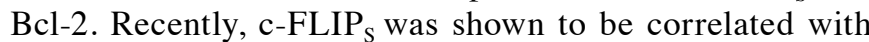
TRAIL resistance in various tumor types, and c-FLIP downregulation has been implicated in chemotherapy-sensitized TRAIL-induced apoptosis $(22,55)$. Several studies have shown that Bcl-2 blocks apoptosis by maintaining mitochondrial function (56). Taken together, our results indicate that c-FLIP and Bcl-2 downregulation contributes to CCT327-facilitated TRAIL-mediated apoptosis.

ROS trigger a variety of cellular responses leading to cell growth, differentiation or cell death (54). ROS generation has been proposed to be involved in death receptor upregulation by cancer chemopreventive agents $(51,52)$. In the present study, we found that induction of ROS was critical for the sensitization of cells to TRAIL by CCT327. Our data revealed that the mechanism by which CCT327 induces DR upregulation is through production of ROS. The antioxidant NAC abolished the upregulation of DR by CCT327. The effect of CCT327 on TRAIL-induced apoptosis was also neutralized by the antioxidant. This reversal was apparently due to inhibition of induction of TRAIL receptors. An important downstream mediator of ROS-induced signaling is the MAPKs $(31,34)$. MAPKs, including ERK1/2, p38 and JNK, have been reported to mediate induction of TRAIL receptors $(47,49)$. Recent studies have shown that activation of ERK, JNK or p38 is also associated with TRIAL-induced-apoptosis via upregulation of DR4/5 (49,50). CCT327 activated ERK1/2 p38 in a time-dependent manner. We questioned whether the activation of p38 and ERK1/2 was the cause or a downstream effect of the upregulation of the TRAIL receptors. Both ERK1/2 inhibitor (Fig. 5B) and p38 inhibitor (Fig. 5D) suppressed the CCT327-induced upregulation of DR4 and DR5. Notably, the presence of the JNK inhibitor had no effect on CCT327-induced DR4 and DR5 expression. CCT327 induced the expression of TRAIL receptors dependent on MAPK, particularly ERK1/2 and p38.

Overall, we demonstrated that CCT327 can sensitize TRAIL-induced apoptosis through the upregulation of DRs mediated by JNK and p38 and the downregulation of cFLIP and other antiapoptotic proteins. CCT327 has potential for application in the treatment of cancer by TRAIL, particularly for tumors that develop resistance to TRAIL.

\section{Acknowledgements}

The authors want to thank Dr Ho for his kind and constructive advice.

\section{References}

1. Wiley SR, Schooley K, Smolak PJ, Din WS, Huang CP, Nicholl JK, Sutherland GR, Smith TD, Rauch C and Smith CA: Identification and characterization of a new member of the TNF family that induces apoptosis. Immunity 3: 673-682, 1995.

2. Pitti RM, Marsters SA, Ruppert S, Donahue CJ, Moore A and Ashkenazi A: Induction of apoptosis by Apo-2 ligand, a new member of the tumor necrosis factor cytokine family. J Biol Chem 271: 12687-12690, 1996.

3. Ashkenazi A, Pai RC, Fong S, Leung S, Lawrence DA, Marsters SA, Blackie C, Chang L, McMurtrey AE, Hebert A, DeForge L, Koumenis IL, Lewis D, Harris L, Bussiere J, Koeppen H, Shahrokh Z and Schwall RH: Safety and antitumor activity of recombinant soluble Apo2 ligand. J Clin Invest 104: 155-162, 1999.

4. Walczak H, Miller RE, Ariail K, Gliniak B, Griffith TS, Kubin M, Chin W, Jones J, Woodward A, Le T, Smith C, Smolak P, Goodwin RG, Rauch CT, Schuh JC and Lynch DH: Tumoricidal activity of tumor necrosis factor-related apoptosis-inducing ligand in vivo. Nat Med 5: 157-163, 1999.

5. Plummer R, Attard G, Pacey S, Li L, Razak A, Perrett R, Barrett M, Judson I, Kaye S, Fox NL, Halpern W, Corey A, Calvert $\mathrm{H}$ and de Bono J: Phase 1 and pharmacokinetic study of lexatumumab in patients with advanced cancers. Clin Cancer Res 13: 6187-6194, 2007.

6. Hotte SJ, Hirte HW, Chen EX, Siu LL, Le LH, Corey A Iacobucci A, MacLean M, Lo L, Fox NL and Oza AM: A phase 1 study of mapatumumab (fully human monoclonal antibody to TRAIL-R1) in patients with advanced solid malignancies. Clin Cancer Res 14: 3450-3455, 2008

7. Camidge DR, Herbst RS, Gordon MS, Eckhardt SG, Kurzrock R, Durbin B, Ing J, Tohnya TM, Sager J, Ashkenazi A, Bray G and Mendelson D: A phase I safety and pharmacokinetic study of the death receptor 5 agonistic antibody PRO95780 in patients with advanced malignancies. Clin Cancer Res 16: 1256-1263, 2010.

8. Forero-Torres A, Infante JR, Waterhouse D, Wong L, Vickers S, Arrowsmith E, He AR, Hart L, Trent D, Wade J, Jin X, Wang Q, Austin T, Rosen M, Beckman R, von Roemeling R, Greenberg $J$ and Saleh M: Phase 2, multicenter, open-label study of tigatuzumab (CS-1008), a humanized monoclonal antibody targeting death receptor 5 , in combination with gemcitabine in chemotherapy-naive patients with unresectable or metastatic pancreatic cancer. Cancer Med 2: 925-932, 2013.

9. Ashkenazi A and Dixit VM: Apoptosis control by death and decoy receptors. Curr Opin Cell Biol 11: 255-260, 1999.

10. Pan G, Ni J, Wei YF, Yu G, Gentz R and Dixit VM: An antagonist decoy receptor and a death domain-containing receptor for TRAIL. Science 277: 815-818, 1997.

11. Pan G, Ni J, Yu G, Wei YF and Dixit VM: TRUNDD, a new member of the TRAIL receptor family that antagonizes TRAIL signalling. FEBS Lett 424: 41-45, 1998.

12. Sheridan JP, Marsters SA, Pitti RM, Gurney A, Skubatch M, Baldwin D, Ramakrishnan L, Gray CL, Baker K, Wood WI, Goddard AD, Godowski P and Ashkenazi A: Control of TRAIL-induced apoptosis by a family of signaling and decoy receptors. Science 277: 818, 1997.

13. Muzio M, Chinnaiyan AM, Kischkel FC, O'Rourke K, Shevchenko A, Ni J, Scaffidi C, Bretz JD, Zhang M, Gentz R, Mann M, Krammer PH, Peter ME and Dixit VM: FLICE, a novel FADD-homologous ICE/CED-3-like protease, is recruited to the CD95 (Fas/APO-1) death - inducing signaling complex. Cell 85: 817-827, 1996.

14. Chaudhary PM, Eby M, Jasmin A, Bookwalter A, Murray J and Hood L: Death receptor 5, a new member of the TNFR family, and DR4 induce FADD-dependent apoptosis and activate the NF- $\kappa$ B pathway. Immunity 7: 821-830, 1997.

15. Aggarwal BB: Signalling pathways of the TNF superfamily: a double-edged sword. Nat Rev Immunol 3: 745-756, 2003.

16. Ashkenazi A, Holland P and Eckhardt SG: Ligand-based targeting of apoptosis in cancer: the potential of recombinant human apoptosis ligand $2 /$ Tumor necrosis factor-related apoptosis-inducing ligand (rhApo2L/TRAIL). J Clin Oncol 26: 3621-3630, 2008.

17. Srivastava RK: TRAIL/Apo-2L: mechanisms and clinical applications in cancer. Neoplasia 3: 535-546, 2001.

18. Suliman A, Lam A, Datta R and Srivastava RK: Intracellular mechanisms of TRAIL: apoptosis through mitochondrial-dependent and -independent pathways. Oncogene 20: 2122-2133, 2001. 
19. Tsujimoto Y and Shimizu S: Bcl-2 family: life-or-death switch FEBS Lett 466: 6-10, 2000.

20. Igney FH and Krammer PH: Death and anti-death: tumour resistance to apoptosis. Nat Rev Cancer 2: 277-288, 2002.

21. Zhang L and Fang B: Mechanisms of resistance to TRAIL-induced apoptosis in cancer. Cancer Gene Ther 12: 228-237, 2005.

22. Irmler M, Thome M, Hahne M, Schneider P, Hofmann K, Steiner V, Bodmer JL, Schröter M, Burns K, Mattmann C, Rimoldi D, French LE and Tschopp J: Inhibition of death receptor signals by cellular FLIP. Nature 388: 190-195, 1997.

23. Griffith TS, Chin WA, Jackson GC, Lynch DH and Kubin MZ: Intracellular regulation of TRAIL-induced apoptosis in human melanoma cells. J Immunol 161: 2833-2840, 1998.

24. Krueger A, Baumann S, Krammer PH and Kirchhoff S: FLICE-inhibitory proteins: regulators of death receptor mediated apoptosis. Mol Cell Biol 21: 8247-8254, 2001.

25. Safa AR, Day TW and Wu CH: Cellular FLICE-like inhibitory protein (C-FLIP): a novel target for cancer therapy. Curr Cancer Drug Targets 8: 37-46, 2008.

26. Cimino F, Esposito F, Ammendola R and Russo T: Gene regulation by reactive oxygen species. Curr Top Cell Regul 35: 123-148, 1997.

27. Dalton TP, Shertzer HG and Puga A: Regulation of gene expression by reactive oxygen. Annu Rev Pharmacol Toxicol 39: 67-101, 1999

28. Sakon S, Xue X, Takekawa M, Sasazuki T, Okazaki T, Kojima Y, Piao JH, Yagita H, Okumura K, Doi T and Nakano H: NF-kappaB inhibits TNF-induced accumulation of ROS that mediate prolonged MAPK activation and necrotic cell death. EMBO J 22: 3898-3909, 2003.

29. Ventura JJ, Cogswell P, Flavell RA, Baldwin AS Jr and Davis RJ: JNK potentiates TNF-stimulated necrosis by increasing the production of cytotoxic reactive oxygen species. Gene Dev 18 : 2905-2915, 2004.

30. Kamata H, Honda S, Maeda S, Chang L, Hirata $\mathrm{H}$ and Karin $\mathrm{M}$ : Reactive oxygen species promote TNFalpha-induced death and sustained JNK activation by inhibiting MAP kinase phosphatases. Cell 120: 649-661, 2005.

31. Zhou JY, Liu Y and Wu GS: The role of mitogen-activated protein kinase phosphatase-1 in oxidative damage-induced cell death. Cancer Res 66: 4888-4894, 2006.

32. Hara H, Ohta M, Ohta K, Kuno S and Adachi T: Increase of antioxidative potential by tert-butylhydroquinone protects against cell death associated with 6-hydroxydopamine-induced oxidative stress in neuroblastoma SH-SY5Y cells. Brain Res Mol Brain Res 119: 125-131, 2003.

33. Jiang H, Ren Y, Zhao J and Feng J: Parkin protects human dopaminergic neuroblastoma cells against dopamine-induced apoptosis. Hum Mol Genet 13: 1745-1754, 2004.

34. Kyriakis JM, Banerjee P, Nikolakaki E, Dai T, Rubie EA, Ahmad MF, Avruch J and Woodgett JR: The stress-activated protein kinase subfamily of c-Jun kinases. Nature 369: 156-160, 1994.

35. Raingeaud J, Gupta S, Rogers JS, Dickens M, Han J, Ulevitch RJ and Davis RJ: Pro-inflammatory cytokines and environmental stress cause p38 mitogen-activated protein kinase activation by dual phosphorylation on tyrosine and threonine. J Biol Chem 270 7420-7426, 1995.

36. Dérijard B, Hibi M, Wu IH, Barrett T, Su B, Deng T, Karin M and Davis RJ: JNK1: a protein kinase stimulated by UV light and Ha-Ras that binds and phosphorylates the c-Jun activation domain. Cell 76: 1025-1037, 1994.

37. Eliopoulos AG, Gallagher NJ, Blake SM, Dawson CW and Young LS: Activation of the p38 mitogen-activated protein kinase pathway by Epstein-Barr virus-encoded latent membrane protein 1 coregulates interleukin- 6 and interleukin- 8 production. J Biol Chem 274: 16085-16096, 1999.

38. Wang WH, Gregori G, Hullinger RL and Andrisani OM: Sustained activation of $\mathrm{p} 38$ mitogen-activated protein kinase and c-Jun N-terminal kinase pathways by hepatitis B virus X protein mediates apoptosis via induction of Fas/FasL and tumor necrosis factor (TNF) receptor 1/TNF-alpha expression. Mol Cell Biol 24: 10352-10365, 2004

39. Nakshatri H, Rice SE and Bhat-Nakshatri P: Antitumor agent parthenolide reverses resistance of breast cancer cells to tumor necrosis factor-related apoptosis-inducing ligand through sustained activation of c-Jun N-terminal kinase. Oncogene 23 7330-7344, 2004.
40. Kuo SC, Lee HZ, Juang JP, Lin YT, Wu TS, Chang JJ, Lednicer D, Paull KD, Lin CM, Hamel E, et al: Synthesis and cytotoxicity of 1,6,7,8-substituted 2-(4'-substituted phenyl)-4-quinolones and related compounds: identification as antimitotic agents interacting with tubulin. J Med Chem 36: 1146-1156, 1993.

41. Chen CT, Hsu MH, Cheng YY, Liu CY, Chou LC, Huang LJ, Wu TS, Yang X, Lee KH and Kuo SC: Synthesis and in vitro anticancer activity of 6,7-methylenedioxy (or 5-hydroxy-6-meth oxy)-2-(substituted selenophenyl) quinolin-4-one analogs. Eur J Med Chem 46: 6046-6056, 2011.

42. Cheng J, Hylander BL, Baer MR, Chen X and Repasky EA: Multiple mechanisms underlie resistance of leukemia cells to Apo2 Ligand/TRAIL. Mol Cancer Ther 5: 1844-1853, 2006.

43. Lin VC, Chou CH, Lin YC, Lin JN, Yu CC, Tang CH, Lin HY and Way TD: Osthole suppresses fatty acid synthase expression in HER2-overexpressing breast cancer cells through modulating Akt/mTOR pathway. J Agric Food Chem 58: 4786-4793, 2010

44. Pan G, O'Rourke K, Chinnaiyan AM, Gentz R, Ebner R, Ni J and Dixit VM: The receptor for the cytotoxic ligand TRAIL. Science 276: 111-113, 1997.

45. Walczak H, Degli-Esposti MA, Johnson RS, Smolak PJ, Waugh JY, Boiani N, Timour MS, Gerhart MJ, Schooley KA, Smith CA, Goodwin RG and Rauch CT: TRAIL-R2: a novel apoptosis-mediating receptor for TRAIL.EMBO J 16: 5386-5397, 1997.

46. Daniel PT, Wieder T, Sturm I and Schulze-Osthoff K: The kiss of death: promises and failures of death receptors and ligands in cancer therapy. Leukemia 15: 1022-1032, 2001.

47. Ohtsuka T and Zhou T: Bisindolylmaleimide VIII enhances DR5-mediated apoptosis through the MKK4/JNK/p38 kinase and the mitochondrial pathways. J Biol Chem 277: 29294-29303, 2002.

48. Izeradjene K, Douglas L, Tillman DM, Delaney AB and Houghton JA: Reactive oxygen species regulate caspase activation in tumor necrosis factor-related apoptosis-inducing ligand-resistant human colon carcinoma cell lines. Cancer Res 65: 7436-7445, 2005.

49. Shenoy K, Wu Y and Pervaiz S: LY303511 enhances TRAIL sensitivity of SHEP-1 neuroblastoma cells via hydrogen peroxide-mediated mitogen-activated protein kinase activation and up-regulation of death receptors. Cancer Res 69: 1941-1950, 2009.

50. Yodkeeree S, Sung B, Limtrakul P and Aggarwal BB: Zerumbone enhances TRAIL-induced apoptosis through the induction of death receptors in human colon cancer cells: Evidence for an essential role of reactive oxygen species. Cancer Res 69: 6581-6589, 2009.

51. Prasad S, Yadav VR, Ravindran J and Aggarwal BB: ROS and CHOP are critical for dibenzylideneacetone to sensitize tumor cells to TRAIL through induction of death receptors and downregulation of cell survival proteins. Cancer Res 71: 538-549, 2011.

52. Kang CH, Moon DO, Choi YH, Choi IW, Moon SK, Kim WJ and Kim GY: Piceatannol enhances TRAIL-induced apoptosis in human leukemia THP-1 cells through Sp1- and ERK-dependent DR5 up-regulation. Toxicol In Vitro 25: 605-612, 2011.

53. Johnstone RW, Frew AJ and Smyth MJ: The TRAIL apoptotic pathway in cancer onset, progression and therapy. Nat Rev Cancer 8: 782-798, 2008.

54. Jacobson MD: Reactive oxygen species and programmed cell death. Trends Biochem Sci 21: 83-86, 1996.

55. Yoon MJ, Kang YJ, Kim IY, Kim EH, Lee JA, Lim JH, Kwon TK and Choi KS: Monensin, a polyether ionophore antibiotic, overcomes TRAIL resistance in glioma cells via endoplasmic reticulum stress, DR5 upregulation and c-FLIP downregulation. Carcinogenesis 34: 1918-1928, 2013.

56. Newmeyer DD and Ferguson-Miller S: Mitochondria: releasing power for life and unleashing the machineries of death. Cell 112: 481-490, 2003. 